\title{
A ve B Kişilik Tiplerine Göre Çalışanların Performans
}

\section{Algılarındaki Farklılık Analizi ${ }^{1}$}

Mustafa Tilki

orcid.org/0000-0001-9570-3304

YL Öğrencisi, Karabük Üniversitesi, Lisansüstü Eğitim Ens. Master's Student, Karabuk Univ., Inst. Of. Graduate Studies

mustafatilki@karabuk.edu.tr

\section{Canan Yildiran} orcid.org/0000-0001-8245-197x

Dr. Öğr. Üye., Karabük Üniversitesi, İşletme Fakültesi Asst. Prof., Karabuk University, Business Faculty cananyildiran@karabuk.edu.tr

Yahya Fidan

orcid.org/0000-0002-5012-3629

Prof. Dr., İstanbul Ticaret Üniversitesi, İşletme Fakültesi Prof. Dr. Istanbul Commerce University, Business Faculty yfidan@ticaret.edu.tr

\section{Öz}

Bireylerin, kendi performansı hakkında bilgi sahibi olması, güçlü ve zayıf yönlerini öğrenmesine, kendisini daha iyi geliştirmesi için neler yapması gerektiğine yardımcı olmaktadır. Bunları ise kendi performansını tespit ederek ulaşabilecektir. Bireylerin göstermiş oldukları reaksiyon, kişilik özelliklerinden bağımsız değildir. Bundan dolayı, bir örgüt içinde bireylerin kişilik tiplerinin (A ve B tipi kişilik) belirlenmesinin ve kendi performansları hakkında bilgi sahibi

\footnotetext{
${ }^{1}$ Bu çalışma Mustafa Tilki'nin Dr. Öğr. Üyesi Canan Yıldıran danışmanlığında “A ve B Tipi Kişilik Tiplerine Göre Çalışanların Performans Algılarındaki Farklılık Analizi" adlı Yüksek Lisans Tezinden üretilmiştir.
} 
olmasının sağlanması önemlidir. Bu araştırmanın amacı sahip olunan kişilik özellikleri ile performans algısı arasındaki ilişkiyi incelemek oluşturmaktadır. Bu amaç kapsamında ise Karabük Üniversitesi'nde çalışan 271 idari personele anket uygulaması yapılmıştır. Araştırmanın anket formu, demografik özellikler, A ve B tipi kişilik ölçeği ve performans değerlendirme ölçeği olmak üzere üç bölümden oluşmaktadır. Verilerin analizinde betimleyici istatistikler, MannWhitney U ve Kruskal-Wallis analiz teknikleri kullanılmıştır. A ve B tipi kişilik özelliklerine sahip bireylerin algıladıkları performansın istatistiksel olarak farklılaşmadığı, bireylerin demografik bilgilerine göre algıladıkları performansın da farklılaşmadığı tespit edilmiştir.

Anahtar Kelimeler: Kişilik, A Tipi Kişilik, B Tipi Kişilik, Performans, Yönetim

\title{
Analysis of Difference in Performance Perception of
}

\section{Employees According to A and B Personality Types}

\begin{abstract}
It helps individuals to have information about their own performance, to learn about their strengths-weaknesses, what they should do to improve themselves better. They'll be able to reach them by determining their own performance. The reaction of individuals isn't independent of their personality traits. It's important to determine the personality types of individuals within an organization, to ensure that they have information about their own performance. The aim of this research is to examine the relationship between personality traits
\end{abstract}


and performance perception. Within the scope of this purpose, a questionnaire was applied to 271 administrative personnel working at Karabuk University. The survey form of the research consists of three parts; demographic characteristics, type A and B personality, performance evaluation scale. Descriptive statistics, Mann-Whitney U and Kruskal-Wallis analysis techniques were used in the analysis of the data. It has been determined that the perceived performance of individuals with type A and B personality traits doesn't differ statistically, the performance perceived by individuals according to their demographic information doesn't differ.

Keywords: Personality, Type A Personality, Type B Personality, Performance, Management

\section{Giriş}

Bireysel farklılıkların araştırılması neredeyse yüz yıldan fazla bir geçmişe sahiptir. Bu araştırmalar kişilik gibi, davranışlardaki farklılıkların tespiti gibi çok sayıda gözlemlenemeyen yani örtülü yapı ile ilgilenmeyi gerektirmektedir (Chamorro-Premuzic, 2014: 2). Bilimin ilerlemesi ve teknolojinin gelişmesi ile birlikte gözleme ve inceleme yöntemleri de artmış bulunmaktadır. Böylece insanın doğası da biraz daha iyi açıklanabilir hal almıştır. Friedman ve Rosenman (1974) tarafından yapılan çalışmada belirli bir davranış kalıpları ile kroner kalp hastalıklarının ilişkili olduğu görülmüşsür (Kirkcaldy, vd., 2002: 1362). Kronik kalp hastalarının nedenlerinden birisinin A tipi kişilik yapısı olduğu birçok araştırmada görülmüştür. A tipi kişilikte olan insanlar rekabetçi, kendisine zaman ayırmayan, aceleci, zaman baskısı hisseden ve strese karşı daha az dayanaklı olan bireyler 
oldukları için kronik kalp rahatsızlığı riski ile daha çok karşılaşmaktadır. B tipi kişilikte olan insanlar ise A tipi kişiliklere göre tam ters özellikleri taşımaktadırlar. B tipi kişilik zaman baskısı hissetmezler, hayatı daha rahat karşılamayı ve yaşamayı severler ve sabırsız değillerdir (Robbins \& Judge, 2015: 143). Ayrıca, A tipi davranışa sahip olan bireyler, B tipi davranışa sahip olan bireylere kıyasla serum kolesterolleri daha yüksek olduğundan dolayı şeker hastası olmaya daha yatkın olabiliyorlar; daha fazla sigara içmek, daha az egzersiz yapmak, kolesterol ve hayvani yağlardan zengin bir beslenme biçimine sahiptirler. Ve tansiyonları daha yüksek olup, koroner damarlardaki bozulmaya yol açacak bazı içsalgı bezleri ise daha fazla çalışmaktadır. Bunun yanı sıra, yemekten sonra aldıkları kolesterolün kandan çıartılması için üç-dört kez daha fazla zamana ihtiyaçları vardır. Bundan dolayı, koroner damarların iç yüzlerinde tehlikeli biçimde yüksek miktarlarda kolesterol birikmesi olmaktadır (Fidan, 2002: 72).

Her iki kişilik özelliklerine bakıldığı zaman, insanların kişilik tipleri ile kurum içindeki davranışlarının ve tutumlarının ilişkili olduğu ve kişilik özellikleri tarafından etkilendiği görülmektedir. Kurum içindeki davranışlar ve tutumlar ise doğal olarak hem yapılan göreve ve işe hem de meslektaşlarına yansıyacağı söylenebilir. Rekabetin hızla arttığı bir çevrede örgütlerin verimli ve etkin çıtılar elde edebilmeleri, sürdürülebilirliklerini sağlayabilmeleri için kullandıkları teknolojilerin yanı sıra insan kaynaklarının da göstereceği performans oldukça önemlidir. Çalışanların, örgüte yaptıkları katkıları, amaçlarına ulaşabilmeleri, iş başarısı, motivasyonu, zayıf yönlerini görebilmeleri, kariyerleri için plan 
yapabilmeleri performansın nasıl algılandığıyla alakalı olduğu görülmektedir. Bundan dolayı performans algısı üzerinde çalışanların A tipi kişiliğe yoksa B tipi kişiliğe mi sahip olduğu önemli bir konu olduğu söylenebilir.

\section{Literatür Taraması}

\subsection{Kişilik Kavramı ve A ve B Tipi Kişilik}

Kişilik (personality) kavramının birçok tanımı bulunmaktadır. Allport (1937) tarafından birçok kişilik tanımlaması tespit edilmiştir. Kişilik kavramının Latince' deki "persona"dan ortaya çıtı̆̆ 1 ve Roma Tiyatrosu ile ilgili olduğu da belirtilmiştir. Klasik Roma Tiyatrosu oyuncuları tarafından simgelemek istedikleri özelliklere göre yüzlerine taktıkları maskelerle oyunlarını sahneleştirdikleri söylenebilir. İşte bu maskeler "persona" olarak adlandırılmaktadır. Aslında böylece kişilik özelliklerinin de farklı olabileceği belirtilmektedir (Erdoğan, 1994: 235).

Bireylerin duygusallıklarının, ilgi duydukları alanların, yetkin oldukları konuların, psikolojik özelliklerinin ve davranışlarının bir bütünü şeklinde ifade edilen kişilik kavramını, Eysenck bireylerin çevresel ve kalıtsal nedenler ile tespit edilmiş olan edimsel davranış biçimlerinin hepsi olarak ifade etmektedir (Baltaş \& Baltaş, 2013: 41).

Bireyin kişilik tipi, içinde bulunduğu çevre ile ele alındığında bireyin dünyaya yaklaşımı, çevresindekilere karşı tavrı, iş ile mücadelesi, ilişkileri gibi insana has yaşam sorunlarına karşı tutumlarının ifade edilmesidir (Adler, 2011: 45).

Kişilik özellikleri araştırmaları, genellikle bireylerin aralarındaki farklılıklar ve benzerlikler ile ilgilidir. Davranışların 
düzenli olması ve gözlemlenebilir kalıpların sınıflandırılması ile başlayarak, bireyin bu değişkenlere bağlı olup ne derecede değişebileceğinin ölçülmesi ile de devam etmektedir. Buradaki amaç ise, genel zaman içinde ölçümün yapılarak stres, performans, sağlık, mutluluk gibi çok geniş bir yelpaze içinde farklılıkları öngörmektir. Kişilik özellikleri bir bireyin tanımının yapılmasının yanı sıra hem bireyler arası kıyaslama yapmak hem de herkesin bireyselliklerini açıklamak amaçlı evrensel bir çerçeve de sunmaktadır (ChamorroPremuzic, 2014: 29).

Davranış ve kişilik birbirleri ile ilişkilidir. İnsanların davranışlarında kendi kişilik özellikleri görülmektedir. İnsanların farklı şekilde davranış göstermeleri ise farklı kişilik özelliklerine sahip olmasından kaynaklanmaktadır (Baransel, vd., 1995: 5).

Kişiliğin oluşması ile ilgili yapılan araştırmalar kişiliğin oluşumunda katılımın mı, çevrenin mi etkili olduğu hakkında net bir sonuca ulaşılamamışsa da literatür çerçevesinde kişilik oluşumunda kalıtımda çevrede etkili olduğu görülmektedir (Robbins \& Judge, 2015: 135).

İnsan davranışlarının parametresinin kişilik olduğu söylenebilir. Böylece bu parametreler davranışların tahmin edilmesinde kullanılmaktadır. Örgüt verimliliğinin arttırılması için yapılan işe uygun kişilikte bireylerin seçilmesi önemli bir konudur. Örneğin, içe kapanık, utangaç, sosyal ilişkilerde rahat olmayan bir birey başkaları ile ilişki ve iletişim içinde olabileceği işler için uygun olmayacaktır. Kişilik tipleri sayesinde bireylerin hangi işlerde başarılı olabileceği tahmin edilebilmektedir (akt. Fidan, 2002: 84-85). 
Literatürde bulunan araştırmalarda kişilik türleri tiplere göre değerlendirilmiştir. Örneğin, Jenkins, Rosenman, Friedman vd. tarafından yapılan çalışmada, kişiliklerin A tipi ve B tipi şeklinde tanımlanmasında koroner kalp yetmezliği ile damar hastalıkları bulunan bireylerin psiko-davranış yapılarının önemli olduğu fark edilmiştir (İbrahimoğlu \& Karayılan, 2012).

A tipi kişilik; A tipi kişiliğin davranış özellikleri olarak, ihtiraslı olması, işlerin sorumluluğunu kendi üstüne alması, yoğun dürtülere sahip olması, zaman ile yarışması söylenebilir. A tipi kişiliğe sahip olanlar, sürekli bir mücadele hali içinde hissederler ve bu mücadele sürecinde ise en kısa zamanda daha fazla işi yapmak veya başarıyı elde etmek isterler (Baltaş \& Baltaş, 2013: 146). A tipi kişiliğe sahip olanlar genellikle diğer insanlar için zamana karşı yarışta frene basanlar olarak algılarlar. Diğger yandan, herhangi bir tartışma ya da tenis maçı olsun hemen bir rekabet hissine ve anlayışına sahip olurlar. Karşısındakini bir rakibi olarak veya işine engel olan kişi olarak algılayıp, iletişimde ve ilişkide karşısındaki ile sürekli bir mücadele hali içinde olmasına sebep olur. A tipine ait olan kişilik davranışı sergileyen bireyler gün içerisinde ve neredeyse her gün bir meydan okuma şeklinde geçmektedir. Küçük ya da büyük çaplı bir iş olsun fark etmeksizin bütün enerjisini ve gücünü o iş için harcamaktadırlar. Psikolog olan Roskies A tipi kişiliğe sahip olanların özellikleri için her anlaşmazlıkları sanki bir nükleer savaş gibidir, şeklinde bir benzetme de bulunmuştur (Lelord \& Andre, 2014: 158-160).

A tipi davranışın, stres ile benzer olmadığı söylenebilir. Bu davranış tipi, insanı mücadele etmeyi gerektiren durumlara yönelten bir davranış tarz olduğu görülmektedir (Fidan, 2002: 88). Çalışma 
hayatında bulunan yöneticilerin, asistanların, personel uzmanlarının ve satış elemanlarının çoğunluğu yapılan işlerin doğasından kaynaklı nedenlerden dolayı da A tipi kişilik sergilemektedirler. Bunlar (Brief, vd., 1981: 11-12):

- İş yükü ve zaman baskısı nedeni ile uzun saatler çalışmak.

- İçsel huzurları için evlerine iş götürmek.

- İş dahilinde yüksek standartlara bağlı kalmak.

- İş kaynaklı sıkıntı haline girerek, diğer çalışanların çalışma şekillerinden rahatsız olmak.

B Tipi Kişilik; B tipi kişilikteki bireyler daha az stres seviyesine sahiptirler. Çoğunlukla, düzenli bir çalışma şekilleri vardır. Ayrıca başarıdan da zevk almaktadırlar. Bu süreçlerde strese girmezler. B tipi kişilik yeni kavramları ve fikirleri keşfetmekten hoşlanırlar. Bu kişiler kaygı çekmedikleri için kalp rahatsızlıkları gibi riskleri de az olmaktadır. B tipi kişilik sakin olup eğlenceli bir tavra sahiplerdir ve daha az rekabetçi oldukları söylenebilir (Long, vd., 2015: 19). B tipi kişiliğe sahip olanlar, terapist, yazar, aktör ve danışman gibi kariyerlere ilgi göstermektedirler (Verma \& Mansuri, 2018: 470). Özetle, B tipi kişiliği olan bir birey rahat, sakin ve uyumlu olmaya yatkın olduğu söylenebilir. Bu kişilerin yaşamları genelde düşük tempolu olduğu için de nadiren koroner rahatsızlıklara yakalanma riskleri söz konusudur (Chamorro-Premuzic, 2014: 35).

Literatürdeki araştırmalar kapsamında A ve B tipi kişiliklere sahip olanların özellikleri kısaca şu şekilde özetlenebilir. A tipi kişilik; işine fazlasıyla odaklanan, mükemmeliyetçi, zaman baskısı hisseden, rekabet duygusuna sahip olan, kaygılı, saldırgan, başarı odaklı, katı tutum sergileyen, daha çok stresli, hareketli ve kendisine daha az 
zaman ayıran şeklinde olduğu söylenebilir. B tipi kişilik; daha az rekabetçi, işlerini bazen oluruna bırakabilen, sabırlı, işinden zevk alan, sosyal olan, kendisine daha çok zaman ayıran, işleri sırasıyla yapan, rahat ve stres ile daha iyi başa çıkan şeklinde olduğu söylenebilir.

\subsection{Performans Kavramı ve Değerlendiricilerin}

\section{Belirlenmesi}

Performans, çalışanların etkin olup olmadıklarının ifade edilmesi için kullanılmaktadır. Çalışanlar, verilen sorumlulukları ve görevleri beklenilen şartlarda yerine getirebildiğinde ve amaçlara ulaşmada başarılı olduğunda performansı için yüksek olduğu belirtilmektedir (Eroğlu, 2011: 456).

İş performansı ise, çalışanların işlerini ne ölçüde iyi yaptıklarıdır. Çoğunlukla, çalışanların kendilerine verilen görevleri yerine getirmelerinin dişında olan bir değerlendirmedir (Sykes \& Venkatesh, 2017: 919).

Görev performansı ise, hammaddenin ürüne ya da hizmete dönüştürülmesinde veya yönetim görevlerinde katkı sağlayacak sorumlulukları ve görevleri yerine getirmek şeklinde tanımlanmaktadır. Örneğin, fabrikadaki malın üretilmesi, bir mağazada malların satışının gerçekleştirilmesi, koordinasyonun sağlanması, lojistik, planlama ve personel faaliyetleri şeklinde olduğu söylenebilir.

Bağlamsal performans ise, takım çalışmasını ve örgütsel hedefleri destekleyerek örgüt başarısı için gönüllü olarak çalışılmasını ifade etmektedir (Koopmans, vd., 2013: 63). Çalışanların değerlendirilmesi açısından bağlamsal performansın önemlidir. 
Çalışanlar arasından birinin bağlamsal performans göstermesi ile diğer çalışanlarda bağlamsal performans gözlenmediğinde direk olarak çalışanın değerlendirilmesine olumlu olarak yansıyacaktır (Bağc1, 2014).

Sağlıklı ve etkin bir şekilde performans değerlendirmenin yapılmasında en önemli husus ise değerlendirmenin kim tarafından yapıldığı 1 oluşturmaktadır (Bingöl, 2013: 383). Kendi kendini değerlendirme, işletme dışındaki kişilerce yapılan değerlendirme, üstler tarafından değerlendirme, müşteriler tarafından değerlendirme, çalışma arkadaşları tarafından değerlendirme, astlar tarafından değerlendirme şeklinde birçok değerlendirme yöntemleri bulunmaktadır. Araştırmanın konusu kapsamında olan kendi kendini değerlendirme yöntemi ele alınmaktadır.

Kendi kendini değerlendirme; çalışanların değerlendirme kriterlerini bilmeleri durumunda bireysel performanslarını değerlendirme konusunda önemli bir konuma sahip oldukları söylenebilir. Birçok çalışan işlerinde neyi iyi yaptıklarını ve geliştirilmesi gereken yönlerini bilmektedir. Çalışanlar imkanları dahilinde kendi performanslarını değerlendirmede objektif olup kendilerini geliştirmek için hamlede bulunacaklardır. Hatta birçok birey kendilerine amirlerinden daha sert bir şekilde eleştiride bulundukları da görülmektedir. Ayrıca, çalışanlar için kendilerinin gelişimi anlam ifade ettiğinden, kendi performanslarını değerlendirebilen çalışanların motivasyonlarının da yüksek olduğu söylenebilir. Kendi kendini değerlendirme, genellikle çalışanlarının gelişimine ve katılımına önem veren yöneticiler tarafından tercih edildiği görülmektedir. Kendi kendini değerlendirmenin ücret 
konusundaki önemi ise pek fazla olmadığı tespit edilmiştir. Kendi kendini değerlendirme sürecinde bazı çalışanların ise kötü performansı bir başkasına iyi performansı ise kendilerine mal etmektedirler (Mondy, 2017: 203-204).

\section{Metodoloji}

\subsection{Araştırmanın Önemi ve Amacı}

Kurumların örgütsel hedeflere ulaşması, çalışanların bilgilerine, yeteneklerine, becerilerine ve göstereceği performanslara bağlıdır. Çalışanların kendi performansları ile ilgili bilgi sahibi olmaları hem güçlü hem zayıf yönlerini öğrenmeleri, kendilerini daha iyi geliştirmeleri için neler yapabileceklerini bilmeleri ve bunları kendi performanslarını değerlendirerek tespit edebilmeleri ile mümkün olabileceği ise önemli bir konudur. Ayrıca, olaylara ve durumlara karşı verilen reaksiyonlar ile kişilik özellikleri ile ilişkilidir. Dolayısı ile bireylerin kişilik tiplerinin (A ve B tipi kişilik) belirlenmesi, kendi performans düzeyleri ile ilgili bilgi sahibi olmalarının sağlanması ise örgütlerin verimliliği için önemli bir konu olduğu söylenebilir.

Çalışmanın amacını ise Friedman ve Rosenman tarafından geliştirilmiş olan A tipi kişilik ve B tipi kişilik sınıflandırma çerçevesinde bir kamu kurumundaki idari personellerin hangi tip kişilik özelliklerine yakınlık gösterdiğini tespit etmeye ve kişilik tiplerinin özelliklerine göre iş hayatlarında bireysel performanslarını nasıl algıladıklarını belirlemeye yönelik bir araştırma oluşturmaktadır. 


\subsection{Araştırmanın Hipotezleri}

Araştırma, bireylerin kişilik özellikleri ile kendi performanslarını algılamaları arasındaki ilişkiyi araştırmak üzere gerçekleştirilmiştir. $\mathrm{Bu}$ çerçevede araştırma sorusu ise; kişilik tiplerinin özelliklerine göre performans algılamalarında farklılık var mıdır? Araştırmanın sorusu çerçevesinde belirlenen hipotezler şöyledir;

$H_{1}$ : A ve B tipi kişiliğe göre performans algısı farklılaşmaktadır.

$\boldsymbol{H}_{2}$ : Performans alg1sı cinsiyete göre farklılaşmaktadır.

$H_{3}$ : Performans algısı yaşa göre farklılaşmaktadır.

H4: Performans algısı Karabük Üniversitesi'nde çalışma süresine göre farklılaşmaktadır.

$H_{5}$ : Performans algısı eğitim durumuna göre farklılaşmaktadır.

H6: Performans algısı iş hayatında bulunma süresine göre farklılaşmaktadır.

\subsection{Araştırmanın Ana Kütlesi ve Örneklemi}

Karabük Üniversitesi'nde görev yapmakta olan idari personel araştırmanın ana kütlesini meydana getirmektedir. Karabük Üniversitesi'nin web (internet) sayfasından 2019 yılının Ekim ayında 464 idari personelin görev yapmakta olduğu verisine ulaşılmıştır. Böylece ana kütleden \%95 güvenilirlik sınırları dahilinde $\% 5$ lik hata payı göz önüne alındığında örneklem büyüklüğü en düşük 196 katılımcı olacak şekilde tespit edilmiştir (Sekaran, 1992: 253; Altunışık, vd., 2005: 127). Çalışma kapsamında oluşturulan anket 2019 yılında Ekim-Kasım ayları arasında kolayda örneklem yolu ile 271 denek üzerinde uygulanmıştır. 


\subsection{Araştırmanın Ölçüm Araçları}

Araştırmanın yöntemi olarak kullanılan ankette, A ve B Tipi kişiliği ölçmeye yönelik yedi soru ifadesinden oluşan ve iki zıt kutuplu Bortner Derecelendirme Ölçeğinin kısa formundan (1966) BRS (Bortner Rating Scale) (Luthans, 2011: 285) yararlanılmıştır. İlgili ölçek Aktaş (2001), Fidan (2002), Özsoy \& Yildız (2013) tarafından da daha önce uygulanmıştır. Ölçek gerçekleştirildikten sonra elde edilen toplam puan üçle çarpılıp değerlendirme gerçekleştirilmektedir (en yüksek puan 168, en düşük puan ise 21). Deneklerin toplam puanı 100'den fazla ise A Tipi kişilik, 100'den az ise B Tipi kişilik olduğu şeklinde belirtilir (Aktaş, 2001: 34). Fidan (2002: 94) tarafından yapılan çalışmada A ve B tipinin geçiş aşamaları olarak A1 ve B1 boyutlarını da ifade etmiştir. Araştırmanın bir diğer ölçeği olan iş performans ölçeği ise, deneklerin kendi bireysel performanslarını nasıl algıladıklarını tespit etmek için dört soru ifadesinden oluşan beşli likert tipi ölçek oluşturmaktadır. Kirkman \& Rosen (1999) tarafından geliştirilmiş olan ölçek Sigler \& Pearson (2000); Altaş \& Çekmecelioğlu (2007); Akkoç vd. (2012); Gül \& Oktay (2009); Kahya (2013) tarafından da daha önce uygulandığı tespit edilmiştir. Ve ayrıca ankette demografik özelliklerin tespiti için sorular da bulunmaktadır. Araştırmada kullanılacak anketin uygulanabilirliğine ilişkin gerekli izinlerin alınabilmesi için Karabük Üniversitesi Sosyal ve Beşeri Bilimler Araştırmaları Etik Kurulu'na gerekli başvuru yapılmış olup, 2019/15-1 sayılı karar ile anketin uygulanabilir olduğuna karar verilmiştir. 


\section{Bulgular}

\subsection{Güvenirlik Analizi}

Çalışmanın güvenirlik analizi ise Cronbach alfa katsayısı kullanılarak hesaplanmıştır. Hesaplanan katsayı 0 ile 1 arasında değerler almaktadır. İlgili değerler; $0 \leq \alpha \leq 0.40$ ise ölçek güvenilir değildir, $0.40 \leq \alpha \leq 0.60$ ise ölçek düşük güvenilirdir, $0.60 \leq \alpha \leq 0.80$ ise ölçek oldukça güvenilirdir, $0.80 \leq \alpha \leq 1$ ise ölçek yüksek düzeyde güvenilirdir (Uzgören, 2012: 54). Çalışmada A ve B tipi kişilik ölçeği ile performans değerlendirme ölçeği olarak kullanılan iki ölçekte toplam on bir soru ifadesi güvenirlik analizi sonucunda; Cronbach Alpha katsayısı .606 olarak tespit edilmiştir. İlgili katsayı $0.60 \leq \alpha \leq 0.80$ aralığına denk geldiğinden dolayı araştırma ölçeğinin güvenilir olduğu söylenebilir.

\subsection{Demografik Değişkenlere Ait Bulgular}

Karabük Üniversitesi idari personel olarak çalışanlara uygulanan anket verilerinden tespit edilen demografik değişkenlere ait bulgular bulunmaktadır. Demografik özellikler kapsamında; cinsiyet, yaş, Karabük Üniversitesi'nde çalışma süresi, eğitim durumu ve iş hayatındaki çalışma sürelerine ilişkin bilgiler bulunmaktadır.

Tablo 1. Cinsiyet Değişkenine İlişkin Dağılımlar

\begin{tabular}{|l|l|l|}
\hline Cinsiyet & $\mathbf{N}$ & $\mathbf{\%}$ \\
\hline Erkek & 172 & 63,5 \\
\hline Kadın & 99 & 36,5 \\
\hline Toplam & 271 & 100 \\
\hline
\end{tabular}

Tablo 1'de görüldüğüü üzere, deneklerin \%63,5'i erkek, \%36,5’i kadındır. 
Tablo 2. Yaş Değişkenine İlişkin Dağılımlar

\begin{tabular}{|l|l|l|}
\hline Yaş & $\mathbf{N}$ & $\mathbf{\%}$ \\
\hline $20-30$ & 41 & 15,1 \\
\hline $31-40$ & 155 & 57,2 \\
\hline $41-50$ & 64 & 23,6 \\
\hline 51 yaş ve üzeri & 11 & 4,1 \\
\hline Toplam & 271 & 100 \\
\hline
\end{tabular}

Tablo 2'de görüldüğü üzere, deneklerin \%15,1'i 20-30 yaş grubu arasında, \%57,2'si 31-40 yaş grubu arasında, \%23,6'sı 41-50 yaş grubu arasında ve \%4,1'i 51 yaş ve üzerinde bulunmaktadır.

Tablo 3. KBÜ’de Çalışma Süresi Değişkenine İlişkin Dağılımlar

\begin{tabular}{|l|l|l|}
\hline $\begin{array}{l}\text { KBÜ'de Çalışma Süresi } \\
\text { (yıl) }\end{array}$ & $\mathbf{N}$ & $\mathbf{\%}$ \\
\hline 1 yıl ve altı & 13 & 4,8 \\
\hline $2-7$ & 119 & 43,9 \\
\hline $8-15$ & 113 & 41,7 \\
\hline $16-21$ & 17 & 6,3 \\
\hline 22 yıl ve üzeri & 9 & 3,3 \\
\hline Toplam & 271 & 100 \\
\hline
\end{tabular}

Tablo 3'te görüldüğü üzere, deneklerin Karabük Üniversitesi'nde çalışma süresi olarak \%4,8'i 1 yıl ve altında, \%43,9'u 2-7 yıl arasında, \%41,7'si 8-15 yıl arasında, \%6,3'ü 16-21 yıl arasında, \%3,3’ü 22 yıl ve üzerinde bulunmaktadır.

Tablo 4. Eğitim Seviyesi Değişkenine İlişkin Dağılımlar

\begin{tabular}{|l|l|l|}
\hline Eğitim Seviyesi & $\mathbf{N}$ & $\mathbf{o}$ \\
\hline Lise & 18 & 6,6 \\
\hline Ön Lisans & 44 & 16,2 \\
\hline Lisans & 166 & 61,3 \\
\hline Yüksek Lisans & 42 & 15,5 \\
\hline Doktora & 1 & 0,4 \\
\hline Toplam & 271 & 100 \\
\hline
\end{tabular}


Tablo 4'te görüldüğü üzere, deneklerin eğitim seviyeleri \%6,6'sı lise, \%16,2'si ön lisans, \%61,3'ü lisans, \%15,5'i yüksek lisans ve $\% 0,4^{\prime}$ ü doktora olarak tespit edilmiştir.

Tablo 5. İş Hayatında Çalışma Süresi Değişkenine İlişkin Dağılımlar

\begin{tabular}{|l|l|l|}
\hline $\begin{array}{l}\text { İş Hayatında Çalışma } \\
\text { Süresi (yıl) }\end{array}$ & $\mathbf{N}$ & $\mathbf{\%}$ \\
\hline 1 yıl ve altı & 4 & 1,5 \\
\hline $2-5$ & 27 & 10 \\
\hline $6-9$ & 68 & 25,1 \\
\hline $10-13$ & 74 & 27,3 \\
\hline $14-17$ & 35 & 12,9 \\
\hline $18-21$ & 30 & 11,1 \\
\hline 22 yıl ve üzeri & 33 & 12,2 \\
\hline Toplam & 271 & 100 \\
\hline
\end{tabular}

Tablo 5 incelendiğinde, deneklerin iş hayatında çalışma süreleri \%1,5'i 1 yıl ve altı, \%10’u 2-5 yıl arasında, \%25,1'i 6-9 yıl arasında, \%27,3’ü 10-13 yıl arasında, \%12,9'u 14-17 yıl arasında, \%11,1'i 18-21 yıl arasında ve \%12,2'si 22 yıl ve üzerinde bulunmaktadır.

\subsection{Hipotezler ile İlgili Analiz}

Araştırmanın hipotezlerini analiz etmek amacı ile MannWhitney U ve Kruskal Wallis testlerinden yararlanılmıştır.

Tablo 6. A ve B Kişilik Tiplerine Göre Performans Algısı

\begin{tabular}{|l|l|l|l|l|l|l|}
\hline Puan & $\begin{array}{l}\text { Kişilik } \\
\text { Tipi }\end{array}$ & N & $\begin{array}{l}\text { Sıra Ort. } \\
(\mathbf{X})\end{array}$ & $\begin{array}{l}\text { Sıra } \\
\text { Top. }\end{array}$ & U & $\mathbf{P}$ \\
\hline $\begin{array}{l}\text { Performans } \\
\text { Alg1s1 }\end{array}$ & A & 187 & 139,1 & 26011 & 7275 & 0,327 \\
\cline { 2 - 8 } & B & 84 & 129,11 & 10845 & & \\
\hline
\end{tabular}


Tablo 6'da görüldüğü üzere, performans algisı sıralama puanları birbirinden farklı olmasına rağmen (A tipi kişilik sıra ortalama puanı $X=139,1$; B tipi kişilik sıra ortalama puanı $X=129,11$ ) performans algısının kişilik tipine göre istatistiksel olarak anlamlı bir farklılık olmadığ 1 tespit edilmiştir $(p=0,071>0,05) . \quad B u$ durumda araştırmanın birinci hipotezi olan " $H_{1}$ : A ve B tipi kişiliğe göre performans algısı farklılaşmaktadır" hipotezi reddedilmiştir.

Tablo 7. Cinsiyete Göre Performans Algısı

\begin{tabular}{|l|l|l|l|l|l|l|}
\hline Puan & Cinsiyet & $\mathbf{N}$ & $\begin{array}{l}\text { Sira Ort. } \\
(\mathbf{X})\end{array}$ & $\begin{array}{l}\text { Sira } \\
\text { Top. }\end{array}$ & U & $\mathbf{P}$ \\
\hline $\begin{array}{l}\text { Performans } \\
\text { Algisı }\end{array}$ & Kadın & 99 & 124,8 & 12355 & 7405 & 0,071 \\
\cline { 2 - 8 } & Erkek & 172 & 142,45 & 24501 & & \\
\hline
\end{tabular}

Tablo 7'de görüldüğü üzere, performans algısı sıralama puanları birbirinden farklı olmasına rağmen (kadın sıra ortalama puanı $X=124,8$; erkek sira ortalama puanı $X=142,45)$ performans algısının cinsiyete göre istatistiksel olarak anlamlı bir farklılık olmadığ1 tespit edilmiştir( $\mathrm{p}=0,071>0,05)$. Bu durumda araştırmanın ikinci hipotezi olan " $\mathrm{H}_{2}$ : Performans algısı cinsiyete göre farklılaşmaktadır" hipotezi reddedilmiştir.

Tablo 8. Yaşa Göre Performans Algısı

\begin{tabular}{|c|c|c|c|c|c|c|}
\hline Puan & Yaş & $\mathbf{N}$ & $\begin{array}{ll}\text { Sira } & \text { Ort. } \\
(X) & \end{array}$ & $X^{2}$ & sd & p \\
\hline \multirow{4}{*}{$\begin{array}{l}\text { Performans } \\
\text { Algis1 }\end{array}$} & $20-30$ & 41 & 115,51 & \multirow{4}{*}{3,553} & \multirow{4}{*}{3} & \multirow{4}{*}{0,314} \\
\hline & $31-40$ & 155 & 138,86 & & & \\
\hline & $41-50$ & 64 & 139,95 & & & \\
\hline & $\begin{array}{l}51 \text { yaş ve } \\
\text { üzeri }\end{array}$ & 11 & 149,05 & & & \\
\hline
\end{tabular}


Tablo 8'de görüldüğü üzere, deneklerin yaş grupları değişkenine göre performans algısı grup sıra ortalamaları arasında istatistiksel olarak anlamlı bir farklılık olmadığı tespit edilmiştir $\left(x^{2}=3,553 ; p=0,314>0,05\right)$. Bu durumda araştırmanın üçüncü hipotezi olan "H3: Performans algısı yaşa göre farklılaşmaktadır" hipotezi reddedilmiştir.

Tablo 9. KBÜ’de Çalışma Süresine Göre Performans Algısı

\begin{tabular}{|c|c|c|c|c|c|c|}
\hline Puan & $\begin{array}{l}\text { KBÜ'de Çalışma } \\
\text { Süresi (yıl) }\end{array}$ & $\mathbf{N}$ & $\begin{array}{l}\text { S1ra Ort. } \\
(X)\end{array}$ & $\mathrm{X}^{2}$ & sd & $\mathbf{p}$ \\
\hline \multirow{5}{*}{$\begin{array}{l}\text { Performans } \\
\text { Alg1sı }\end{array}$} & 1 yıl ve altı & 13 & 129,19 & \multirow{5}{*}{1,904} & \multirow{5}{*}{4} & \multirow{5}{*}{0,753} \\
\hline & $2-7$ & 119 & 129,68 & & & \\
\hline & $8-15$ & 113 & 143,25 & & & \\
\hline & $16-21$ & 17 & 138,47 & & & \\
\hline & 22 yıl ve üzeri & 9 & 133,78 & & & \\
\hline
\end{tabular}

Tablo 9'da görüldüğü üzere, deneklerin Karabük Üniversitesi'nde çalışma süresi (yıl) değişkenine göre performans alg1sı grup sira ortalamaları arasında istatistiksel olarak anlamlı bir farklılık olmadığ1 tespit edilmiştir $\left(x^{2}=1,904 ; p=0,753>0,05\right) . \quad B u$ durumda araştırmanın dördüncü hipotezi olan " $H_{4}$ : Performans algısı KBÜ'de çalışma süresine göre farklılaşmaktadır" hipotezi reddedilmiştir.

Tablo 10. Eğitim Seviyesine Göre Performans Alg1sı

\begin{tabular}{|l|l|l|l|l|l|l|}
\hline Puan & Eğitim & $\mathbf{N}$ & $\begin{array}{l}\text { Sira Ort. } \\
(\mathbf{X})\end{array}$ & $\mathbf{X}^{2}$ & sd & $\mathbf{p}$ \\
\hline \multirow{4}{*}{$\begin{array}{l}\text { Performans } \\
\text { Alg1s1 }\end{array}$} & Lise & 18 & 123,72 & & & \\
\cline { 2 - 5 } & Ön Lisans & 44 & 149,59 & \multirow{3}{*}{5,172} & \multirow{3}{*}{4} & \multirow{2}{*}{0,270} \\
\cline { 2 - 5 } & Lisans & 166 & 130,23 & & & \\
\cline { 2 - 5 } & $\begin{array}{l}\text { Yüksek } \\
\text { Lisans }\end{array}$ & 42 & 151,45 & & & \\
\cline { 2 - 5 } & Doktora & 1 & 67,50 & & & \\
\hline
\end{tabular}


Tablo 10'da görüldüğü üzere, deneklerin eğitim durumu seviyesi değişkenine göre performans algısı grup sıra ortalamaları arasında istatistiksel olarak anlamlı bir farklılık olmadığı tespit edilmiştir $\left(x^{2}=5,172 ; \quad p=0,270>0,05\right)$. Bu durumda araştırmanın dördüncü hipotezi olan " $\boldsymbol{H}_{5}$ : Performans alg1sı eğitim durumuna göre farklılaşmaktadır" hipotezi reddedilmiştir.

Tablo 11. İş Hayatında Bulunma Süresine Göre Performans Algısı

\begin{tabular}{|c|c|c|c|c|c|c|}
\hline \multirow[t]{2}{*}{ Puan } & Hayatında & \multirow[t]{2}{*}{$\mathbf{N}$} & \multirow{2}{*}{$\begin{array}{ll}\text { Sira } & \text { Ort. } \\
(X) & \end{array}$} & \multirow[t]{2}{*}{$X^{2}$} & \multirow[t]{2}{*}{ sd } & \multirow[t]{2}{*}{$\mathbf{p}$} \\
\hline & $\begin{array}{l}\text { Bulunma Süresi } \\
(y 11)\end{array}$ & & & & & \\
\hline \multirow{7}{*}{$\begin{array}{l}\text { Performans } \\
\text { Alg1s1 }\end{array}$} & 1 yıl ve altı & 4 & 137,00 & \multirow{7}{*}{6,612} & \multirow{7}{*}{6} & \multirow{7}{*}{0,358} \\
\hline & $2-5$ & 27 & 123,35 & & & \\
\hline & $6-9$ & 68 & 124,94 & & & \\
\hline & $10-13$ & 74 & 147,10 & & & \\
\hline & $14-17$ & 35 & 154,56 & & & \\
\hline & $18-21$ & 30 & 122,00 & & & \\
\hline & 22 yıl ve üzeri & 33 & 137,17 & & & \\
\hline
\end{tabular}

Tablo 11'de görüldüğü üzere, deneklerin iş hayatında bulunma süresi değişkenine göre performans algısı grup sıra ortalamaları arasında istatistiksel olarak anlamlı bir farklılık olmadığı tespit edilmiştir $\left(x^{2}=6,612 ; p=0,358>0,05\right)$. Bu durumda araştırmanın beşinci hipotezi olan " $H_{6}$ : Performans algısı iş hayatında bulunma süresine göre farklılaşmaktadır" hipotezi reddedilmiştir.

\section{Sonuç}

Çalışanların kişilikleri karşılaştıkları olaylar ve durumlar karşısında davranış biçimlerini etkilediği düşünülmektedir. Bu durumda da bireylerin davranış biçimleri iş hayatlarındaki performansı da etkileyeceği söylenebilir. Ayrıca birey davranışlarını 
görev gerekliliği, sorumluluğu, zorluk derecesi gibi göreve ait özellikler ile örgütün sosyal yapısı ve kültürü de etkilemektedir.

Literatürdeki araştırmalar incelendiğinde, Üzüm ve Şenol (2020) çalışmalarında havayolu işletmelerinde çalışan bireylerin kişilik tipleri ile devamsızlık arasında istatistiksel ilişkinin olmadığı tespit edilmiştir.

Aşkun (2018) çalışmasında Antalya şehrinde sahne sanatları organizasyon şirketi kapsamında istihdam eden yabancı uyruklu olan sahne sanatçılarının iş performanslarını kişilik ve demografik değişkenleri açısından incelemiştir. Sanatçıların kendi performanslarını değerlendirmede; algıladıkları performansların cinsiyet değişkenine göre farklılaşmadığı, ama yaş, uyruk ve eğitim seviyesine göre farklılaştığı sonucunu elde etmiştir.

Güler ve Basım (2016) tarafından yapılan araştırmada Ankara'da bulunan üniversitelerdeki öğrencilere yönelik genel yetenek ölçümlerinde performans ve süre ilişkisinin kişilik tipleri açısından incelemişlerdir. Genel olarak bilişsel yetenek test performansı ve test süresi ile A tipi kişilik arasında anlamlı bir ilişki tespit edilmemiştir. B tipi kişilikte ise süre ve yaş ile genel bilişsel yetenek performansı arasında anlamlı bir ilişki tespit edilmiştir.

Güney (2015) tarafından yapılan araştırmada telekomünikasyon sektör çalışanlarının iş tatmininin performansları üzerine etkisi incelenmiş olup katılımcılar tarafından algılanan performanslarının demografik değişkenlere göre farklılaşmadığını tespit etmişlerdir.

Araştırma kapsamında, Karabük Üniversitesi idari personelin kişilik tiplerinin belirlenmesi, demografik değişkenlere göre 
algıladıkları performansları üzerinde bir etkisinin olup olmadığı ve son olarak ise A tipi kişiliklerin ve B tipi kişiliklerin algıladıkları performanslarda farklılık olup olmadığ

Çalışmada A ve B tipi kişiliklerin performans algılarının farklı olup olmadığ 1 incelendiğinde, kişilik tipleri arasında performanslarının algılanmasında farklılık olmadığı tespit edilmiştir. $\mathrm{Bu}$ durumda araştırma kapsamındaki $H_{1}$ hipotezi reddedilmiştir. A tipi kişilerin performansa bakışları ile B tipi kişilerin performansa bakışları arasında çok keskin ayrımlar bulunmaktadır. Araştırmamızda bu durumun ayırt edici olmaması deneklerin hassasiyetlerinden kaynaklandığı düşünülebilir. Bu sonucun bir nedeni, deneklerin yargıları tam olarak anlayamamış olmaları da olabilir. Çalışmada performans algılarının demografik değişkenlerden biri olan cinsiyete göre anlamlı bir farklılık olup olmadığı incelendiğinde, cinsiyet değişkenine göre anlamlı bir farklılık tespit edilmemiş olup, böylece $H_{2}$ hipotezi reddedilmiştir. Çalışmada performans algılarının demografik değişkenlerden biri olan yaşa göre anlamlı bir farklılık olup olmadığ grupları arasında için sıralama ortalamalarının birbirine yakın değerler alması sebebi ile yaş değişkeninin performans algısı üzerinde herhangi bir etkisi olmadığ 1 ve böylece çalışmadaki $H_{3}$ reddedilmiştir. Çalışmada performans algılarının demografik değişkenlerden biri olan Karabük Üniversitesi'nde çalışma süresine göre anlamlı bir farklılık olup olmadığı incelendiğinde, personelin performans algılarının ilgili kurumda çalışma süresine göre anlamlı bir farklılık tespit edilmemiş olup, $H_{4}$ reddedilmiştir. Çalışmada performans algılarının demografik değişkenlerden biri olan eğitim seviyesi 
durumuna göre anlamlı bir farklılık olup olmadığı incelendiğinde, katılımcların performans algılarının eğitim seviyelerine göre anlamlı bir farklılık tespit edilmediği görülmüş olup, çalışmanın $H_{5}$ olan hipotezi reddedilmiştir. Çalışmada performans algılarının demografik değişkenlerden biri olan iş hayatında bulunma süresine göre anlamlı bir farklılık olup olmadığ incelendiğinde, idari personelin performans algılarının ilgili değişkene göre anlamlı bir farklılık tespit edilmemiştir. Böylece, çalışma kapsamındaki hipotezlerden sonuncusu olan $\mathrm{H}_{6}$ hipotezi de reddedilmiştir. Araştırma kapsamında elde edilen sonuçlar literatürde bulunan çalışmaları destekleyen benzer neticelere ulaşıldığı görülmektedir.

Katılımciların performans algılarının hem demografik değişkenlere göre hem de kişilik tiplerine göre değişmediği görülmüş̧tür. Elde edilen sonuçlar için öğrenilmiş veya kalıplaşmış performans algılarının var olduğu düşünülebilir.

Yapılan araştırma çerçevesinde elde edilen sonuçlar doğrultusunda ortaya çıkan öneriler aşağıdaki gibidir.

- Daha kapsamlı veriler elde edebilmek için araştırmanın daha farklı hizmet birimlerinden oluşan kamu kurumlarında yapılması önerilebilir.

- $\quad$ İlgili çalışma çerçevesi doğrultusunda kamu ve özel sektör olarak ele alınıp hem inceleme hem de karşılaştırma yapılabilir.

- Bireylerin performans algılamalarının değişmeme nedenleri araştırılabilir ve ayrıca nedenler arasında sosyolojik, psikolojik etkenler olup olmadığı araştırma konusu olarak incelenmesi önerilebilir. Böylece interdisiplinli bir araştırma yapılmış olup, sonuçlar çok boyutlu bütünsel bir perspektiften görülebilir. 
- Demografik değişkenler kapsamında soru nicelikleri ve nitelikleri geliştirilebilir.

- Akademik personel katılımcilar olarak da tercih edilebilir.

Son olarak, B tipi kişiliğe sahip olanlar hem ilişkilerinden hem de toplumsa hayatta daha kolay ve rahat bir kişilik sergileyenler olarak tanımlandığı görülmektedir. Buna karşın, A tipi kişiliklerin davranış tarzının örgütlerin ve işletmelerin başarısına olan katkısından dolayı, bu kişilik davranışlarının değiştirilmesinden ziyade, A tipi kişilik davranış tarzının insan sağlığı üzerindeki olumsuz etkilerini gidermeye yönelik çalışmalara ihtiyaç bulunmaktadır (Fidan, 2002: 93). Yapılması gereken, örgütlerin yönetici mevkilerinde bulunan A tipi kişilik tarzını sergileyenlerin sağlıkları üzerindeki olumsuzlukları elimine etmeye yönelik çalışmaların artırılmasıdır.

\section{Kaynakça}

Adler, A. (2011). İnsan Tabiatın Tanıma. İstanbul: Kumsaati.

Akkoç, İ., Çalışkan, A. \& Turunç, Ö. (2012). “Örgütlerde gelişim kültürü ve algılanan örgütsel desteğin iş tatmini ve iş performansına etkisi: Güvenin aracılık rolü", Yönetim ve Ekonomi: Celal Bayar Üniversitesi İktisadi ve İdari Bilimler Fakültesi Dergisi, 105-135.

Aktaş, A. M. (2001). “Bir Kamu Kuruluşunun Üst Düzey Yöneticilerinin İş Stresi ve Kişilik Özellikleri”, Ankara Üniversitesi SBF Dergisi, 25-42.

Altaş, S. S. \& Çekmecelioğlu, H. G. (2007). “İş Tatmini, Örgütsel Bağlılık ve Örgütsel Vatandaşlık Davranışının İş Performansı 
Üzerindeki Etkileri: Bir Araştırma", Aralık 10, 2019 tarihinde http://dspace.marmara.edu.tr/handle/11424/39803 adresinden alındı.

Altunışık, R., Çoşkun, R. \& Yıldırım, E. (2005). Sosyal Bilimlerde Araştırma Yöntemleri: SPSS Uygulamalı. İstanbul: Avcı Ofset.

Aşkun, V. (2018). İş Performansının Kişilik Özellikleri ve Demografik Değişkenlere Göre İncelenmesi. Yüksek Lisans Tezi, Akdeniz Üniversitesi Sosyal Bilimler Enstitüsü, Antalya.

Bağcl, Z. (2014). “Çalışanların İş Doyumunun Görev ve Bağlamsal Performansları Üzerindeki Etkisi", Yönetim ve Ekonomi Araştırmaları Dergisi, 58-72.

Baltaş, Z. \& Baltaş, A. (2013). Stres ve Başa Çıkma Yolları. İstanbul: Remzi Kitabevi (31.bs).

Baransel, A., Paksoy, M. vd. (1995). “Tepe Yöneticilerinin Kişilik Özellikleri ve Davranış Biçimlerine İlişkin Bir Araştırma", İ. Ü. İşletme Fakültesi Dergisi, c. 24, s. 1, 5-22.

Bingöl, D. (2013). İnsan Kaynakları Yönetimi. İstanbul: Beta.

Brief, A. P., Schuler, R. S. \& Sell, M. V. (1981). Managing Job Stress. Boston: Little-Brown.

Chamorro-Premuzic, T. (2014). Kişilik ve Bireysel Farklılıklar. İstanbul: İstanbul Ticaret Üniversitesi Yayınları.

Erdoğan, İ. (1994). İşletmelerde Davranış. İstanbul: Beta Yayincilik.

Eroğlu, F. (2011). Davranış Bilimleri. İstanbul: Beta Yayıncılık. Fidan, Y. (2002). Girişimcilik ve Girişimci Özellikleri (Sivas İli Örneği). İstanbul: Beta Yayıncılık. 
Gül, H. \& Oktay, E. (2009). “Ücret, Kariyer, İş Tatmini ve Performans Arasındaki İlişkiler: Karaman Valiliğinde Bir Uygulama", Selçuk Üniversitesi Sosyal Bilimler Enstitüsü Dergisi, 223-238.

Güler, M. \& Basım, H. N. (2016). “Genel Bilişsel Yetenek Ölçümlerinde Süre ve Performans İlişkisinde A Tipi Kişiliğin Rolü", Yönetim ve Ekonomi, 189-202.

Güney, Z. (2015). İş Tatmini, 360 Derece Performans Değerleme ve Algılanan Performans İlişkisi: Bir Telekomünikasyon Şirketi Örneği. Doktora Tezi, Süleyman Demirel Üniversitesi Sosyal Bilimler Enstitüsü, Isparta.

İbrahimoğlu, N. \& Karayılan, D. (2012). “A ve B tipi Kişilik Özellikleri ile Zaman Yönetimi Davranışları Arasındaki İlişkiler", Dumlupmar Üniversitesi Sosyal Bilimler Dergisi, 33, 251-262.

Kahya, C. (2013). “Örgütsel Sinizm, İş Performansını Etkiler mi? İş Tatminin Aracılık Etkisi", Global Journal of Economics and Business Studies, 34-46.

Kirkcaldy, B. D., Shephard, R. J. \& Furnham, A. F. (2002). “The Influence of Type a Behaviour and Locus of Control Upon Job Satisfaction and Occupational Health", Personality and Individual Differences, 1361-1371.

Kirkman, B. L. \& Rosen, B. (1999). “Beyond self-management: Antecedents and Consequences of Team Empowerment", Academy of Management Journal, 42, 58-78.

Koopmans, L., Bernaards, C. M., Hildebrandt, V. H., Vet, H. C. \& Beek, A. J. (2013). “Measuring Individual Work Performance- 
Identifying and Selecting Indicators", Work: A Journal of Prevention, Assessment E Rehabilitation, 62-81.

Lelord, F. \& Andre, C. (2014). "Zor Kişilikler"le Yaşamak. İstanbul: İletişim.

Long, C. S., Alifiah, M. N., Kowang, T. O. \& Ching, C. W. (2015). “The Relationship Between Self-Leadership, Personality and Job Satisfaction: A Review", Journal of Sustainable Development, 16-23.

Luthans, F. (2011). Organizational Behavior. Mc Graw Hill.

Mondy, R. W. (2017). Insan Kaynakları Yönetimi. Ankara: Nobel Akademik Yayıncilık.

Özsoy, E. \& Yıldız, G. (2013). “Kişilik Kavramının Örgütler Açısından Önemi: Bir Literatür Taraması", İşletme Bilim Dergisi, 1(2), 112.

Robbins, S. \& Judge, T. (2015). Örgütsel Davranış. Ankara: Nobel Akademik Yayıncılık.

Sekaran, U. (1992). Research Methods for Business: A Skill Building Approach, 2nd Edition, New York.

Sigler, T. H. \& Pearson, C. M. (2000). “Creating an empowering culture: examining the relationship between organizational culture and perceptions of empowerment", Journal of Quality Management, 2752.

Sykes, T. A. \& Venkatesh, V. (2017). “Explaining PostImplementation Employee System Use and Job Performance: Impacts of the Content and Source of Social Network Ties", MIS Quarterly, 917936. 
Uzgören, N. (2012). Bilimsel Araştırmalarda Kullanılan Temel İstatistiksel Yöntemler ve SPSS Uygulamaları. Bursa: Ekin Yayınevi.

Üzüm, B. \& Şenol, L. (2020). “Tip A ve Tip B Kişilik Tipi ile Devamsızlık İlişkisi: Bir Araştırma", İstanbul Ticaret Üniversitesi Sosyal Bilimler Dergisi, 257-267.

Verma, R. \& Mansuri, M. G. (2018). “Personality Type and Respiratory Diseases", Indian Journal of Health and Wellbeing, 470-472. 